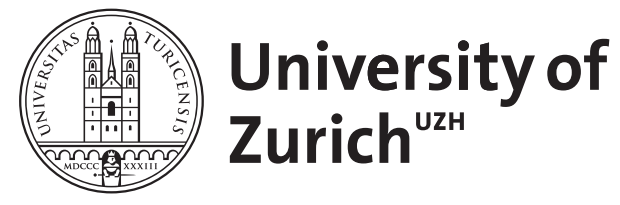

\title{
Apocalyptic Writings in Qumran and the Community's Idea of History
}

Frey, Jörg

DOI: https://doi.org/10.1515/9783110714746-005

Posted at the Zurich Open Repository and Archive, University of Zurich

ZORA URL: https://doi.org/10.5167/uzh-214532

Book Section

Published Version

Originally published at:

Frey, Jörg (2021). Apocalyptic Writings in Qumran and the Community's Idea of History. In: Schröter, Jens; Nicklas, Tobias; Puig i Tàrrech, Armand. Dreams, Visions, Imaginations: Jewish, Christian and Gnostic Views of the World to Come. Berlin, Boston: De Gruyter, 89-116.

DOI: https://doi.org/10.1515/9783110714746-005 


\title{
Apocalyptic Writings in Qumran and the Community's Idea of History
}

\begin{abstract}
Die Qumran-Funde haben das wissenschaftliche Bild von Apokalyptik entscheidend verändert und eine erhebliche Zahl bekannter und neuer apokalyptischer Texte zum Vorschein gebracht. Nach einer Klärung der Begriffe (Qumran-'Gemeinde,' -'Corpus,' -'Bibliothek') werden die wesentlichen apokalyptischen Texte aus dem Fund aufgeführt. Im speziellen Fokus auf die QumranGemeinde werden dann die wichtigsten als apokalyptisch zu bestimmenden Motive in den gruppenspezifischen ('sectarian') Texten vorgeführt: die Vorstellung eines eschatologischen Gerichts und einer Auferstehung der Toten, die Reflexion über die Ursprünge des Bösen, die Rede von verschiedenen eschatologischen Gegenspielern sowie eine ausgeprägte Angelologie mit der spezifischen Vorstellung, dass die Gemeinde in ihrem irdischen Gottesdienst mit den Engeln verbunden sei.
\end{abstract}

Der zweite Teil des Aufsatzes widmet sich dann speziell dem Verständnis von Zeit und Geschichte in der Qumran-Gemeinde. Unverhüllte historische Referenzen begegnen in den Texten praktisch nicht, doch ist eine eigene Lokalisierung in der Geschichte Israels in wichtigen Passagen der Damaskusschrift gegeben. Die Qumran-Gemeinde nimmt Modelle der Geschichtsperiodisierung (nach heptadischen Schemata) auf (z. B. aus dem Jubiläenbuch oder der Zehnwochenapokalypse). In spezifischem Endzeitbewusstsein beziehen die Pescharim die biblischen Texte auf die Gegenwart bzw. die eigene Gemeindegeschichte, wobei der Habakuk-Pescher schon mit einer Dehnung der Zeit über den erwarteten Punkt des Endes hinaus umgehen muss.

Der Umgang mit Zeit und Geschichte zeigt einerseits eine starke Anknüpfung an apokalyptische Traditionen, er belegt aber auch, dass diese für die Qumran-Gemeinschaft zur Bewältigung der eigenen Gegenwartserfahrungen hilfreich und tragfähig gewesen sein mussten.

Keywords: Apocalyptic; Apocalypses; Qumran; History; Eschatology; Pesharim

1 The current essay was initially a paper read at the Barcelona conference on May $9^{\text {th }}$, 2019. The structure of the original paper has been preserved, and the references to secondary literature are strictly limited. For many details, I refer to my own earlier works, which have now been collected in the volume: J. Frey, Qumran, Early Judaism, and New Testament Interpretation, ed. J.N. Cerone, WUNT 424 (Tübingen: Mohr Siebeck, 2019). 
The Qumran discoveries with their approximately 900 fragmentary Hebrew and Aramaic manuscripts from the $3^{\text {rd }}$ century BCE to the $1^{\text {st }}$ century CE have substantially improved our understanding of early Jewish and early Christian Apocalypticism. ${ }^{2}$ The Qumran Corpus has brought to our knowledge a large number of hitherto unknown writings that can be considered "apocalypses" or - in a wider sense - "apocalyptic" writings. It has helped us arrive at a much clearer definition of what constitutes the literary genre of an "apocalypse,"3 develop a more multi-faceted pattern of apocalyptic sub-genres, and more generally develop a refined understanding of the character and intention of Jewish and Christian apocalypticism.

Most importantly, the Qumran discoveries have resulted in a re-dating of the historical origins of Jewish Apocalypticism: Whereas before the discoveries, the rise of Jewish apocalypticism was usually linked with the Maccabean crisis and the composition of the Book of Daniel, so that usually other "apocalyptic" texts such as Isa $26: 19^{4}$ or also the book of Enoch (1 Enoch) ${ }^{5}$ were also dated to that

2 Cf. generally J. Frey, “The Qumran Discoveries and the Understanding of Apocalypticism,” in idem, Qumran, Early Judaism, and New Testament Interpretation, 195-241. The present article adopts and further elaborates some aspects of that work. For an assessment of the Qumran Corpus as a whole, see J. Frey, “Qumran: An Overview,” in idem, Qumran, Early Judaism, and New Testament Interpretation, 45-81.

3 Here we can note in particular the definition established by John Collins: “'Apocalypse' is a genre of revelatory literature with a narrative framework, in which a revelation is mediated by an otherworldly being to a human recipient, disclosing a supernatural reality which is both temporal, insofar as it envisages eschatological salvation, and spatial, insofar as it involves another, supernatural world." See J.J. Collins, "Introduction: Towards the Morphology of a Genre," in Apocalypse: The Morphology of a Genre, ed. J.J. Collins, Semeia 14 (Misoula, MT: Society of Biblical Literature, 1979), 1-20, here 9. See further the contribution of J.J. Collins and L. Arcari to this volume. See also the supplement to the earlier definition by A. Yarbro Collins, "Introduction: Early Christian Apocalypticism," in Early Christian Apocalypticism: Genre and Social Setting, ed. A. Yarbro Collins, Semeia 36 (Decatur, GA: Society of Biblical Literature, 1986), 1-11, here 7: "intended to interpret present, earthly circumstances in light of the supernatural world and of the future, and to influence both the understanding and the behavior of the audience by means of divine authority." Cf. further the more recent reflections in J.J. Collins, "Genre, Ideology and Social Movement in Jewish Apocalypticism," in Mysteries and Revelations: Apocalyptic Studies since the Uppsala Colloquium, ed. J.J. Collins and J.H. Charlesworth, JSPSup 9 (Sheffield: JSOT, 1991), 11-32, here 15-16.

4 Cf., for example, the view of Isa 26:19 with 25:8a as late additions from the second half of the $2^{\text {nd }}$ century BCE in O. Kaiser, Der Prophet Jesaja. Kapitel 13-39, $3^{\text {rd }}$ ed., ATD 18 (Göttingen: Vandenhoeck \& Ruprecht, 1983), 173-177.

5 Cf. G.W.E. Nickelsburg, 1 Enoch, vol. 1, Hermeneia, (Minneapolis, MN: Fortress, 2001), 304 n. 14, in explicit revision of the interpretation he had offered in an earlier work (cf. idem, Resurrection, Immortality and Eternal Life in Intertestamental Judaism, HTS 26 [Cambridge, MA: Har- 
period or even later, the Qumran discoveries have brought to light manuscript evidence of several sections of the book of Enoch that go back to the $3^{\text {rd }}$ century BCE and thus suggest a much earlier origin of the apocalyptic tradition. This means that original intentions and core themes of apocalypticism are best illuminated not from the Book of Daniel or from Revelation and other so-called "historical" apocalypses, but rather from the early Enochic tradition that predates those biblical paradigms of apocalyptic thought. The fundamental ideas of the apocalyptic movement can now be explained on the basis of calendrical wisdom and the mythological tale of the Watchers (1 En. 6-12), which is the earliest Jewish aetiology of the origins of evil in the world that also includes the hope for its final removal in an eschatological judgment. ${ }^{6}$ Here, the motifs of evil and its primordial causes, final restoration or even salvation, and a final judgment of the living and the dead are rooted in a kind of mythological theodicy. Rather than merely being a kind of undue speculation about future times or a phantastic mode of coping with unfulfilled expectations, ${ }^{7}$ apocalypticism develops a symbolic world which could serve its readers as a means of understanding their world, their history, their destiny, ${ }^{8}$ as well as the fate of their adversaries.

\section{Apocalypticism and the Qumran Community}

The question how Qumran is or was related to apocalypticism has been intensely debated. At the famous Uppsala conference, the late Hartmut Stegemann claim-

vard University Press, 1972], 134). While he had put 1 Enoch 22 after Dan 12 there, he now reverses the relationship and explains Dan 12 against the background to 1 Enoch 22 and 24:2-27:2 assuming that "these chapters provide a scenario that was probably taken for granted by the author of Daniel 12:2."

6 On the interpretation of the Watchers episode, see recently M.E. Götte, Von den Wächtern zu Adam: Frühjüdische Mythen über die Ursprünge des Bösen und ihre frühchristliche Rezeption, WUNT 2/426 (Tübingen: Mohr Siebeck, 2016), 40-78.

7 Thus the very negative view of Jewish apocalypticism in earlier Protestant scholarship from Friedrich Lücke and Adolf Hilgenfeld to Julius Wellhausen and the school of Rudolf Bultmann. On this, cf. J. Frey, "Jesus und die Apokalyptik," in idem, Von Jesus zur neutestamentlichen Theologie: Kleine Schriften II, ed. B. Schliesser, WUNT 368 (Tübingen: Mohr Siebeck, 2017), 85-157, here 89-100, see further J.M. Schmid, Die jüdische Apokalyptik: Die Geschichte ihrer Erforschung von den Anfängen bis zu den Textfunden von Qumran (Neukirchen-Vluyn: Neukirchener Verlag, 1969) and K. Müller, "Die frühjüdische Apokalyptik: Anmerkungen zu den Anfängen ihrer Geschichte, zu ihrem Erscheinungsbild und zu ihrer theologischen Wertung," in idem, Studien zur frühjüdischen Apokalyptik, SBAB 11 (Stuttgart: Katholisches Bibelwerk, 1991), 36-174.

8 Cf. the interpretation of the worldview of early apocalypses in Nickelsburg, 1 Enoch 1 (see n. 5), $37-56$. 
ed that the Qumran community cannot be considered an apocalyptic movement, because the Qumran community itself did not author texts of the genre "apocalypse." Stegemann rightly points to the fact that that the texts that can be classified as "apocalypses," such as the book of Enoch (1 Enoch) or the Aramaic New Jerusalem Document, do not originate within the yahad community or, at best, do not contain clear elements that point to an origin within that "sectarian" community. However, Stegemann's view that apocalypticism was marginal to the Qumranites - as it was also, according to his view, marginal to the Hebrew Bible and to the New Testament - has received widespread rejection. Scholars such as Florentino García Martínez and John Collins have confirmed the view that apocalypticism is a fundamental prerequisite for understanding the views of the Qumran community. ${ }^{10}$ The evidence is twofold, first from range of texts contained in the Qumran Corpus or collected by the Qumranians in their library, and second from a number of apocalyptic themes displayed in the group-specific texts from which we can get more precise insights into the views of the Qumran Sectarians. In the present contribution, I will give a brief overview of the presence of apocalyptic writings and themes in the Qumran community ${ }^{11}$ before we can, then, more thoroughly discuss the Qumranites' views of history and of their own place within it or an within end-time sequence of events.

\section{1 'Qumran,' 'Community,' 'Corpus,' and 'Library': A Preliminary Clarification of the Terms}

Just for clarification, I have to indicate my use of the terms and my view of the "Qumran Community." The Scrolls discovered in the 11 Caves near Khirbet Qumran belong together and are, as archaeological artefacts, connected with the set-

9 H. Stegemann, "Die Bedeutung der Qumranfunde zur Erforschung der Apokalyptik," in Apocalypticism in the Mediterranean World and the Near East, ed. D. Hellholm, $2^{\text {nd }}$ ed. (Tübingen: Mohr Siebeck, 1989), 495-530.

10 F. García Martínez, Foreword to Qumran and Apocalyptic. Studies on the Aramaic Texts from Qumran, ed. idem, StTDJ 9 (Leiden: Brill, 1992), ix - xvi, here x; cf. also idem, "Les traditions apocalyptiques à Qumrân,” in Apocalypses et voyages dans l'au-delà, ed. C. Kappler (Paris: Cerf, 1987), 201-235; further J.J. Collins, "Was the Dead Sea Sect an Apocalyptic Movement," in idem, Seers, Sibyls and Sages in Hellenistic and Roman Judaism, JSJSup 54 (Leiden: Brill, 1997), 261-286; idem, Apocalypticism in the Dead Sea Scrolls (London: Routledge, 1997); idem, “Apocalypticism and Literary Genre in the Dead Sea Scrolls," in The Dead Sea Scrolls After Fifty Years: A Comprehensive Assessment, vol. 2, ed. P.W. Flint and J.C. VanderKam (Leiden et al.: Brill, 1999), 403-430.

11 Based on Frey, “The Qumran Discoveries” (see n. 2), 206-216. 
tlement of Khirbet Qumran. The critical debate of the last two or three decades has shown that both should not be interpreted independently, but are related in various respects, with the result that the collection or at least the deposit of the scrolls most likely did not happen without the community living or working at Khirbet Qumran. ${ }^{12}$ However, some of the texts in which a certain community (the yahad) is mentioned and described (e.g., the "Community Rule" 1QS) were written before the beginnings of the settlement at Khirbet Qumran and thus testify to communities or circles at various places in Judaea or even beyond. This means that the "Qumran Community" is not merely the (small) group of people that actually lived and worked at the location of Khirbet Qumran but a much larger faction or movement within Second Temple Judaism which is characterized by a "sectarian" division from the larger body of Judaeans, by a particular interpretation of the Scriptures, and by a special community structure which is described in slightly varying forms in the group-specific rule texts from Qumran, such as the "Community Rule" (S), the "Damascus Document" (D), and some other texts.

Among the "Qumran Corpus," that is the texts found at Qumran, we can distinguish between texts with elements that show distinctive signs of an origin within that wider, but "sectarian" community, so that they can be considered group-specific or "sectarian" texts that represent the thought of the community, and other texts without such specific features with an origin prior to or outside of the yahad community. Among those texts adopted are, of course, all the biblical texts, probably all texts composed in Aramaic, and also a large number of "parabiblical" or exegetical, sapiential, and liturgical texts. In fact, the majority of writings contained in the Qumran Corpus is not "sectarian" in the sense defined.

On the other hand, the Qumran Corpus is not just a random assembly of texts but is a selection of texts based upon certain criteria. Not all the texts from the corpus are indicative for the views of the community, but the shape of the corpus points to a deliberate interest in certain texts and, possibly, also to a neglect of others. Thus, the large number of calendrical texts representing the 364-day lunisolar calendar or discussing calendrical related issues is certainly no coincidence, but instead points to the fact that calendrical issues were fundamental for the Qumran Community. On the other hand, the complete lack of the Maccabean corpus or related texts might also not be a coincidence. So the Qumran Corpus shows clear signs of a deliberate selection of texts and can, therefore, in spite of the inner diversity texts, be considered a "library."

12 Cf. my comprehensive discussion in J. Frey, "Qumran and Archaeology," in idem, Qumran, Early Judaism, and New Testament Interpretation, 121-161. 


\section{2 'Apocalypses' in the Qumran Library ${ }^{13}$}

Within the Qumran Corpus (which can be supplemented by some other locations near the Dead Sea), there are ca. 200 biblical manuscripts, and, with all due caution, the number of manuscripts for each of the books may be indicative for the interest the community had in a particular book. ${ }^{14}$

(a) In this respect, it is important that the book of Daniel is attested in a large number of manuscripts and is supplemented by a number of additional manuscripts representing other texts related to the Daniel tradition. ${ }^{15}$ With eight manuscripts, Daniel even outnumbers the important prophetic books of Jeremiah (6) or Ezekiel (6). All chapters of the book are attested with the exception of Dan $12 .{ }^{16}$ This shows the high appreciation of the book in the circles that formed the background of the library.

This is confirmed by other, previously unknown texts related to Daniel and the Daniel tradition, including a Prayer of Nabonidus (4Q242), closely connected to Daniel 4; three Aramaic manuscripts (4Q243-245), representing possibly two different pseudo-Daniel texts; ${ }^{17}$ and also the famous "Son of God Text" (4Q246) that echoes Dan $7 .{ }^{18}$ Although the identity of the one called "Son of God" is con-

13 For the following passage, cf. the more extensive discussion in Frey, "The Qumran Discoveries" (see n. 2), 206-216.

14 Cf. also J. Frey, "The Authority of the Scriptures of Israel in the Qumran Corpus," in idem, Qumran, Early Judaism, and New Testament Interpretation, 403-428.

15 Cf. J.J. Collins, "The Book of Daniel and the Dead Sea Scrolls," in idem, Scriptures and Sectarianism: Essays on the Dead Sea Scrolls, WUNT 332 (Tübingen: Mohr Siebeck, 2004), 87-101. 16 Cf. E. Tov, "Categorized List of the "Biblical Texts," in The Texts from the Judean Desert: Indices and Introduction to the Discoveries in the Judaean Desert Series, ed. idem, DJD 39 (Oxford: Oxford University Press, 2002), 165-184, here 176; on the extant texts, cf. E. Ulrich, "Index of Passages in the 'Biblical Texts,"' in The Texts from the Judean Desert: Indices and Introduction to the Discoveries in the Judaean Desert Series, ed. E. Tov, DJD 39 (Oxford: Oxford University Press, 2002), 185-201, here 200. On the Daniel manuscripts, see P.W. Flint, "The Prophet Daniel at Qumran,” in Eschatology, Messianism, and the Dead Sea Scrolls, ed. C.A. Evans and P.W. Flint (Grand Rapids, MI: Eerdmans, 1997), 41-60, and Collins, "Apocalypticism and Literary Genre" (see n. 10), $410-413$.

174 Q243 and 244 overlap, whereas the 4Q245 probably represents a different work. Cf. J.J. Collins and P.W. Flint, "Pseudo-Daniel," in Qumran Cave 4 XVII: Parabiblical Texts, ed. G. Brooke et al., Part 3, DJD 22 (Oxford: Clarendon Press, 1996), 95-163, here 133 and 153.

18 É. Puech, "4QApocryphe de Daniel ar," in Qumran Cave 4 XVII, ed. G. Brooke et al., DJD 22 (Oxford: Oxford University Press, 1996), 165-184; cf. also J. Zimmermann, Messianische Texte aus Qumran, WUNT 2/104 (Tübingen: Mohr Siebeck, 1998), 128-169. 
troversial, ${ }^{19}$ the apocalyptic character of the text is clear. Probably within a court scene, a vision of the king is explained by a wise man (like Daniel), and the explanation includes an overview of history. Another text clearly related to Daniel is 4Q Four Kingdoms (4Q522/553), a visionary report that seems to use the familiar four kingdoms schema from Dan 2 and Dan 7.

Due to the fact that these texts are written in Aramaic, it is likely that the Qumran community simply adopted them in the same way it adopted the book of Daniel. However, with the presence of all these texts, the Qumran library evidences a remarkable degree of reception of the book of Daniel and the Danielic tradition, especially in view of the fact that the book of Daniel was composed not too long before the beginnings of the Qumran movement. Daniel is also quoted (as a "prophet") in two group-specific texts, 11QMelchizedek and the Midrash on Eschatology (4Q174 olim Florilegium, and 4Q177). ${ }^{20}$

(b) Even more important than the texts from the Daniel tradition are the manuscripts with texts from the Enochic tradition. ${ }^{21}$ Their discovery has fundamentally changed our view not merely of the Enochic tradition, but of apocalypticism in general. Before the Qumran discoveries, 1 Enoch was fully known only in Old Ethiopian (Ge'ez) manuscripts and, apart from this, in some fragments in Greek and short citations in Syriac, Coptic, and Latin. From the Qumran library, we have become familiar with numerous Aramaic manuscripts containing material from all parts of the Ethiopian book of 1 Enoch, except the Parables (1 En. 37-71), and also manuscripts of the Book of the Giants, previously known only from Manichean texts. ${ }^{22}$

The sheer number of manuscripts is impressive: There are four manuscripts of the Astronomical Book (4Q208-211), with the earliest one (4QEnastr ${ }^{a}$ ) crafted

19 The question is whether the figure is a positive messianic figure or is he instead a negative anti-messianic figure or ruler such as Antiochus IV Epiphanes; cf. the sober overview in J.A. Fitzmyer, "The Aramaic 'Son of God' Text from Qumran Cave 4 (4Q246)," in idem, The Dead Sea Scrolls and Christian Origins (Grand Rapids, MI: Eerdmans, 2000), 41-61.

20 Cf. Collins, "The Book of Daniel" (see n. 15), 102-104.

21 Cf. the foundational work of J.T. Milik, The Books of Enoch: The Aramaic Fragments from Qumran (Oxford: Oxford University Press, 1976). See further G.W.E. Nickelsburg, "The Books of Enoch at Qumran. What We Know and What We Need to Think about," in Antikes Judentum und Frühes Christentum, Festschrift Hartmut Stegemann, ed. B. Kollmann, W. Reinbold, and A. Steudel, BZNW 97 (Berlin: de Gruyter, 1999), 99-113; idem, 1 Enoch (see n. 5), vol. 1, 9-12. 22 Cf. L.T. Stuckenbruck, The Book of Giants from Qumran, TSAJ 63 (Tübingen: Mohr Siebeck, 1997). 
in the late $3^{\text {rd }}$ or early $2^{\text {nd }}$ century BCE, ${ }^{23}$ seven more manuscripts of other parts of 1 Enoch, with the earliest one $\left(4 \mathrm{QEn} \mathrm{n}^{\mathrm{a}}\right.$ ar) containing the opening chapters of the Book of Watchers from the first half of the $2^{\text {nd }}$ century $B C E,{ }^{24}$ and nine or ten manuscripts of the Book of Giants. Regardless of whether the Astronomical Book can be classified as "apocalyptic" or not, ${ }^{25}$ the discovery is of greatest significance for the question of the beginnings and foundational motifs of Jewish apocalypticism. The manuscripts not only physically point to an early date of those early apocalyptic texts, before the Maccabean crisis, some of them also attest to the beginning collection of different parts of the Enochic "Pentateuch,"26 with only the part of the Parables of Enoch still missing at Qumran.

Scholars usually consider Jubilees a "rewritten Bible" text, but due to its literary design as an angel's dictation to Moses from the heavenly tablets, it could also be classified as an "apocalypse" in the sense of Collins's definition. ${ }^{27}$ In the Damascus Document (CD XVI, 3-4), Jubilees is even mentioned with its title. This shows the connection between apocalyptic tradition and halakic interests (and the link between Enochic and Mosaic traditions) which can already be found in Qumran and was further developed within the Qumran community.

The intense reception of Enochic traditions even raises the question whether Enoch had obtained a kind of scriptural authority within the Qumran community. ${ }^{28}$ This is not surprising in view of the fact that even in the letter of Jude from the beginning of the $2^{\text {nd }}$ century CE, Enoch is quoted as Scripture and considered a prophet (Jude 14). ${ }^{29}$ Further confirmation of such a quasi-canonical authority may be taken from a small fragment (4Q247) classified by the editors as a Pesher of the Apocalypse of Weeks, which is a commentary on an Enochic passage similar to the way other Scriptures like the prophets and psalms are interpreted.

23 Cf. Milik, The Books of Enoch (see n. 21), 7, 273; the more recent discussion is noted in G.W.E. Nickelsburg and J.C. VanderKam, 1 Enoch 2: A Commentary on the Book of 1 Enoch, Chapters 37-82, Hermeneia (Minneapolis, MN: Fortress Press, 2012), 339-341.

24 Milik, Books of Enoch (see n. 23), 140; Nickelsburg, 1 Enoch 2 (see n. 23), 9.

25 This essentially depends on whether $1 \mathrm{En} .80-81$ is an original part of the book; see M. Albani, Astronomie und Schöpfungsglaube: Untersuchungen zum Astronomischen Henochbuch, WMANT 68 (Neukirchen-Vluyn: Neukirchener Verlag, 1994), 33-38. Cf. also the debate on the literary unity of chs. 72-82 in Nickelsburg and VanderKam, 1 Enoch 2 (see n. 23), 359-365. $264 \mathrm{QEn}{ }^{\mathrm{c}}$ ar includes the Book of the Watchers, the Book of Dream Vision, as well as the Epistle of Enoch all in one manuscript.

27 Cf. also J.J. Collins, The Apocalyptic Imagination (New York, NY: Crossroad, 1984), 66-67.

28 Cf. Frey, "The Authority of the Scriptures of Israel” (see n. 14), 423-424.

29 On the quotation of 1 En. 1:8-9 in Jude 1:14 and the authority of Enoch in parts of the early church, see J. Frey, The Letter of Jude and the Second Letter of Peter: A Theological Commentary, trans. K. Ess (Waco, TX: Baylor University Press, 2018), 118-129. 
However, the Qumran rule texts do not quote or draw on Enochic passages, thus the evidence remains somewhat unclear. But be that as it may, the significance of calendric and eschatological traditions for the community is evident, and this confirms the vivid interest in apocalyptic motifs and thus the influence of apocalyptic thought on the Qumran Community.

(c) I can only mention some additional texts from the Qumran Corpus that can be classified as apocalypses: There is the Aramaic New Jerusalem Document, preserved in six manuscripts, which is formally a narrative about a visionary who is led around by an angel who interprets what is seen and, therefore, even fits the specific definition of apocalyptic genre. ${ }^{30}$ The Aramaic Words of Michael 4Q529 are also an apocalypse, which includes heavenly details followed by a historical, theological, and eschatological prophecy. Other texts, mostly in Aramaic, are linked to Levi or related figures, such as Qahat and Amram and thus represent priestly interests, together with an apocalyptic worldview. In particular the socalled Visions of Amram prefigure the later genre of the Testaments of the Twelve Patriarchs. ${ }^{31}$ The content of this work, preserved in seven or eight manuscripts includes a conspicuous, dualistic scene of the dispute between two angels between whom Amram is required to choose. This cosmic dualism of powers ${ }^{32}$ clearly points to a dualistic thought structure and shows that the dualistic language with the opposition of the terms "sons of light" and "sons of darkness" (4Q548 $1 \mathrm{II}-2,10-11$ and 15-16), or "sons of lies" and "sons of truth" (4Q548 1 II-2, 8-9) which is so characteristic for later Qumran sectarian thought probably originates in early apocalyptic priestly circles.

All these texts more or less fit the features of the genre apocalypse. Most of them, except Jubilees, are composed in Aramaic, which indicates that they were not composed by members of the yahad community, which most likely only chose Hebrew for their compositions.

A large number of additional texts are not apocalypses by genre, but display motifs otherwise characteristic of apocalypses. For example, the heavenly liturgy

30 See J. Frey, "The New Jerusalem Text in Its Historical and Traditio-Historical Context," in idem, Qumran, Early Judaism, and New Testament Interpretation, 349-368.

31 Cf. J. Frey, “On the Origins of the Genre 'Literary Testament': Farewell Discourses in the Qumran Library and Their Relevance for the History of the Genre," in idem, Qumran, Early Judaism, and New Testament Interpretation, ed. J.N. Cerone, WUNT 424 (Tübingen: Mohr Siebeck, 2019), 325-348, in particular 338-339; idem, “Apocalyptic Dualism: Its Formation and History,” in idem, Qumran, Early Judaism, and New Testament Interpretation, here 308-309.

32 See J. Frey, "Different Patterns of Dualistic Thought in the Qumran Library," in idem, Qumran, Early Judaism, and New Testament Interpretation, 243-299, here 278-295, and idem, “Apocalyptic Dualism” (see n. 31), 308-309 and 316-320. 
of the Songs of the Sabbath Sacrifices with its interest in angelology and the heavenly world; sapiential texts such as Mysteries and Instruction, in which wisdom traditions and practical instructions are combined with cosmological and eschatological or even apocalyptic motifs; or the famous War Rule (M), which is actually a rule text that presents a "liturgical" rule for the eschatological war, which also contains a significant number of apocalyptic elements.

Summing up, in the Qumran Corpus, there are numerous apocalypses of various types or sub-genres (heavenly journeys, historical apocalypses, symbolic apocalypses), mostly written in Aramaic and probably adopted by the Qumran Community. From the other texts mentioned, the Wisdom texts were probably not composed within the yahad, and the War Rule was possibly based on an earlier pre-sectarian version. Most difficult is the discussion of the origins of the Songs of the Sabbath Sacrifice that - because of its genre - does not contain any clear signs of a sectarian origin, but can also be read as an expression of the theological views of the community. ${ }^{33}$ Regardless of the uncertainties of origin, the adoption of apocalyptic genres and motifs in the Qumran Corpus is clear.

\subsection{Apocalyptic Motifs in the Qumran Sectarian Texts}

This can be further confirmed from the adoption of apocalyptic motifs in texts composed within the yahad. I can only briefly mention some of the most interesting motifs and give some selected references. ${ }^{34}$

\subsubsection{Eschatological Judgment and Resurrection of the Dead ${ }^{35}$}

One of the most important elements in both otherworldly journeys and historical apocalypses is the expectation of a final judgment that will result in the removal or destruction of wickedness. In the Qumran Corpus, such an expectation is not only attested in non-sectarian apocalypses such as the Enochic texts or the likely

33 See now the argument by my doctoral student M.R. Jost, Engelgemeinschaft im irdischen Gottesdienst: Studien zu Texten aus Qumran und dem Neuen Testament, WUNT 2/505 (Tübingen: Mohr Siebeck, 2019), 187-188.

34 See the more extensive discussion in Frey, "The Qumran Discoveries” (see n. 2), 216-230. 35 Cf. Collins, "Apocalypticism and Literary Genre” (see n. 10), 410-413. 
pre-sectarian Treatise on the Two Spirits (1QS III, 13-IV, 26), ${ }^{36}$ according to which a final visitation of the good and the wicked at "the appointed time" (1QS IV, 20) is predetermined. It is also clearly mentioned in central texts that originate within the community. ${ }^{37}$

Thus, in its very beginning, the Damascus Document expresses the expectation that God will "dispute with all flesh" (CD I, 2), and later the document envisages a final judgment as a punishment of the wicked (VII, 9; XIX, 6). The Songs of the Sage (4Q511) expect God's wrath "against all flesh, and a judgement of vengeance to terminate the wickedness" (4Q511 35 1). The Hodayot present final judgment as including the whole creation $\left(1 \mathrm{QH}^{\mathrm{a}} \mathrm{VI}, 5-6\right)$, which includes not only the judgement of the wicked $\left(1 \mathrm{QH}^{\mathrm{a}} \mathrm{X}, 24\right)$ but also "the vindication of the individual protagonist." 38 Sometimes, the expectation of judgment is only focused on the wicked, as the authors or the tradents behind the text consider themselves part of the lot of light or the remnant designed for final deliverance. Thus, the Community Rule (1QS V, 11-13) expects the judgment of all men of injustice. Community members should keep their distance from such men. Within this rule text, judgment is even considered the effect of the curses of the covenant for those Israelites who did not enter the covenant and will thus face "everlasting annihilation without there being any remnant." 39 The examples could be multiplied. It is clear that the apocalyptic idea of judgment - expressed in various ways - is also adopted in texts from the yahad.

More difficult is the question whether the Qumran sectarians also envisaged an eschatological resurrection of the dead. ${ }^{40}$ Such a hope for resurrection is clearly expressed in the book of Daniel and other non-sectarian texts. Wellknown examples are the famous Pseudo-Ezekiel Text 4Q385 where the resurrection of the people from Ezekiel 37 is now interpreted in terms of an individual resurrection, ${ }^{41}$ and the so-called "Messianic apocalypse" 4 Q521 which is in fact a compilation of scriptural expectations (from Isaiah and Ps 145), with the

36 On this text, see Frey, "Different Patterns" (see n. 32), 256-267; also idem, "The Rule of the Community," in Early Jewish Literature: An Anthology, ed. B. Embry, R. Herms, and A.T. Wright, vol. 2 (Grand Rapids, MI: Eerdmans, 2018), 95-127, here 100-103.

37 For the following passages, cf. A.L.A. Hogeterp, Expectations of the End: A Comparative Traditio-Historical Study of Eschatological, Apocalyptic and Messianic Ideas in the Dead Sea Scrolls and the New Testament, STDJ 83 (Leiden et al.: Brill, 2009), 376-379.

38 Hogeterp, Expectations of the End (see n. 37), 377

39 Hogeterp, Expectations of the End (see n. 37), 378.

$40 \mathrm{Cf}$. also the comprehensive investigation by É. Puech, La croyance des Esséniens en la vie future: immortalité, résurrection, vie éternelle?, EtBib 22 (Paris: Gabalda, 1993).

41 Cf. Hogeterp, Expectations of the End (see n. 37), 272-274. 
famous wording "He will make the dead live, he will proclaim good news to the poor" (4Q521 $2 \mathrm{ii}, 12){ }^{42}$

The testimony from the documents of a clear sectarian origin is less clear. Some of the texts adduced as an evidence for a belief in the resurrection of the dead from the Hodayot, for example, are so metaphorical that the theme cannot be clearly identified. ${ }^{43}$ The phrase "to raise the worms of the dead from the dust, to an ever(lasting) community" $\left(1 \mathrm{QH}^{\mathrm{a}} \mathrm{XIX}, 12\right)$ can be read as a view of the present state of the community (in communion with the angels ${ }^{44}$ ), but not as an unequivocal reference to a bodily, eschatological resurrection. Possibly, other topics were more predominant to the Qumran community, such as, for instance, the present elevation to the communion with the heavenly beings ${ }^{45}$ so that "the conceptualization of bodily resurrection receded to the background." ${ }^{36}$ But in spite of that, the adoption of such a great number of texts that clearly share the hope for an eschatological resurrection of the dead, shows that the community certainly "did not negate such afterlife beliefs" 47 but shared them as well as part of the apocalyptic heritage adopted from its precursor groups.

\subsubsection{The Origins of Evil}

One of the most important motifs at the beginnings of the Jewish apocalyptic tradition is the question about the origins of evil..$^{48}$ In the Enochic Book of the Watchers, this topic is pivotal, and the current status of the world is explained by reference to the primordial fall of the Watchers, which is interpreted as a first transgression of the boundaries between the heavenly and the earthly

42 Hogeterp, Expectations of the End (see n. 37), 283; on the text in particular M. Becker, "Die 'messianische Apokalypse' 4Q521 und der Interpretationsrahmen der Taten Jesu," in Apokalyptik und Qumran, ed. M. Becker and J. Frey, Einblicke 10 (Paderborn: Bonifatius, 2007), 247-303. 43 Cf. also H. Lichtenberger, "Auferstehung in den Qumranfunden," in Auferstehung-Resurrection, ed. F. Avemarie and H. Lichtenberger, WUNT 135 (Tübingen: Mohr Siebeck, 2001), 79-91. 44 Cf. Jost, Engelgemeinschaft (see n. 33), 146-149.

45 See Jost, Engelgemeinschaft (see n. 33), 196-201.

46 Hogeterp, Expectations of the End (see n. 37), 292.

47 Hogeterp, Expectations of the End (see n. 37), 292.

48 J.J. Collins, "The Origin of Evil in Apocalyptic Literature and in the Qumran Community," in idem, Seers, Sibyls and Sages in Hellenistic-Roman Judaism, JSJSup 54 (Leiden: Brill, 1997), 287300; F. García Martínez, "Apocalypticism in the Dead Sea Scrolls," in The Encyclopedia of Apocalypticism, ed. J.J. Collins, vol. 1 (New York, NY: Bloomsbury, 2002), 162-192, here 166-172. On the variety of concepts, see now Götte, Von den Wächtern (see n. 6). 
world, causing evil and destruction. ${ }^{49}$ While the biblical story of creation and paradise ultimately leaves open the question, the development of the Watcher myth is the first Jewish attempt at an explanation of the current state of the world, including an outlook on a future restitution and a removal of evil.

With regard to the Qumran Corpus, however, a negative observation is striking: The narrative of the Watchers is received within the book of Jubilees, which is part of the Enochic tradition, but it is almost completely ignored within the writings from the Qumran community. The Damascus Document (CD II, 15-16) alludes to the Watchers, but they only function as a paradigmatic warning for sinners. ${ }^{50}$ Only in the so-called Pesher on the Periods (4Q180 I, 7-8) might there be a reference to the fall of the Watchers. ${ }^{51}$ In the sectarian texts, the Watchers are not used as an explanation for the sinfulness of the world. This is possibly due to the fact that the sectarians did not see the status of the world as a mere consequence of the sin of angels, but more openly blamed a certain eschatological opponent, Belial, for misleading humans. ${ }^{52}$ Furthermore, they strictly upheld the idea of the divine control and predestination of everything that happened, so that the tale of a primordial fall of angels did not really fit into that view.

There is another prominent pattern that explains the existence of evil in the world and the temptation of the pious. The Treatise on the Two Spirits in 1QS III, 13-IV, 26 offers a much more rigorous image determined by God's predestination, leaving no room for an original "fall" or a primordial fall of the angelic beings: ${ }^{53}$ Instead, God created and instituted two spirits from the very beginning to guide humankind in different ways according to his predestination and to lead them to different ethical actions as well as conflicting eschatological ends. In this text, even the pious are part of this struggle, which has seized their own hearts and will rage in them until the end. Although this text probably originates in pre-sectarian sapiential circles, it certainly had a considerable influence on the Qumran sectarian community. But what was adopted is not the idea of the

49 See Götte, Von den Wächtern (see n. 6), 60-78; cf. also L.T. Stuckenbruck, "The Origins of Evil in Jewish Apocalyptic Tradition: The Interpretation of Genesis 6:1-4 in the Second and Third Centuries B.C.E.," in The Fall of the Angels, ed. C. Auffahrt and L.T. Stuckenbruck, TBN 6 (Leiden: Brill, 2004), 87-118.

50 Cf. the New Testament's mention of the watchers in Jude 6 and again in 2 Pet 2:4-5.

51 See Götte, Von den Wächtern (see n. 6), 107-109; on the Reception of the myth of the Watchers $78-128$.

52 Götte, Von den Wächtern (see n. 6), 110.

53 On this text, see Frey, "Different Patterns of Dualistic Thought in the Qumran Library" (see n. 32), 256-267. 
two spirits but the predestinarian view of the world and history with the idea of an eternal election (1QS IV, 22, 26) which was of central importance for the theology of the yahad. ${ }^{54}$

\subsubsection{Eschatological Opponents ${ }^{55}$}

Another pivotal apocalyptic topic is the mention of (various) eschatological opponent figures. In emerging apocalypticism, there are a number of terms that are increasingly used in the sense of a personal figure who leads evil powers or afflicts humans. This is true for "Satan," 56 who is not truly an evil figure in the Hebrew Bible until Chronicles (1 Chr 21:1), ${ }^{57}$ and only later becomes the central opponent in Jewish and Christian tradition. Other names are "malakh ha-mastema" (angel of enmity) (CD XVI, 5), or also "Mastema" (as the angelic leader of the demons is called in Jubilees), "Malki-resha" (king of evil), used for the opponent in the Visions of Amram, or also "Angel of Darkness," as the opponent of the "Prince of Light" is called in the Treatise on the Two Spirits (1QS 3 20-21). In the yahad, however, the primary name for the chief of the evil powers is "Belial," a name which like "Satan" or "Mastema" is a personification of an originally unpersonal term ("nothingness") but now personalized as the crystallization point of all opposition against God and the afflictions of the community. With "Belial" as the central evil figure, opposed to God and his elect, the thought world of the Qumran community is distinctively apocalyptic.

Closely connected with the mention of evil and an evil host or its chief are expectations of a final "visitation" (as it is expressed in the Treatise on the Two Spirits 1QS IV, 6, 11, 26), that is, an eschatological act or series of actions initiated by God which brings about not only the removal of evil and the judgment and final condemnation of the evil powers, but also the purification of the pious and the restoration of a salvific condition. In some texts, most explicitly and directly in the War Rule (M), these final acts are imagined as an eschatological war between God or his principal agent (Michael) and Belial and the related forces, with the result of the final victory of God's "lot" or the faithful.

54 Cf. CD II, 7; 1QH VI, $23-24$ (= XIV, 11-12 Sukenik) and 4Q181 1 II, 5; See the detailed discussion in Frey, "Different Patterns" (see n. 32), 267-273.

55 Cf. García Martínez, “Apocalypticism in the Dead Sea Scrolls” (see n. 48), 184-190.

56 Cf. Götte, Von den Wächtern (see n. 6), 200-205.

57 In Job 1-2 and Zech 3:1-2, "satan" is used with an article, so that it is still more a functional term, rather than a proper name. 


\subsubsection{Angelology and the Motif of a Present Communion with the Angels}

A third motif, which can also be regarded as 'apocalyptic' in the broader sense but is developed in a very specific manner in the yahad, is the idea of communion with the heavenly beings. ${ }^{58}$ Whereas the Jewish apocalyptic tradition has widely developed angelological ideas ${ }^{59}$ and also reckoned with an eschatological communion with heavenly beings, ${ }^{60}$ the distinctive view in the Qumran community was that such an invisible communion is already realized at present, that is, that the sectarian community is now elevated from the dust and is considered worthy to be united with the heavenly angels, and that this communion with the angels is reality whenever the community comes together for worship and praise.

Thus, in the organization of the yahad, there is a decisive modification of the earlier apocalyptic views. For in the group-specific texts, the conviction is expressed that the community of the pious itself is a "temple," a "human temple," as it is phrased in the "Midrash on Eschatology" (4QMidrEschat III, 6). ${ }^{61}$ The temple terminology is metaphorically transferred to the community, and the community is the sanctuary in which "works of gratitude" are offered to God (4QMidrEschat III, 7). ${ }^{62}$ In the Rule of the Community (1 QS VIII, 5), the community is referred to as a "holy house for Israel" that should be separated and united as "the most holy," as "the house of the community for Israel, who walk in

58 On this, cf. Jost, Engelgemeinschaft (see n. 33), whose investigation now includes a wider range of texts than had been available in earlier works such as H.-W. Kuhn, Enderwartung und gegenwärtiges Heil: Untersuchungen zu den Gemeindeliedern von Qumran mit einem Anhang über Eschatologie und Gegenwart in der Verkündigung Jesu, SUNT 4 (Göttingen: Vandenhoeck \& Ruprecht, 1966).

59 Concerning early Jewish angelology, see the important work by M. Mach, Entwicklungsstadien des jüdischen Engelglaubens in vorrabbinischer Zeit, TSAJ 34 (Tübingen: Mohr Siebeck, 1992), also M.J. Davidson, Angels at Qumran: A Comparative Study of 1 Enoch 1-36, 72-108 and Sectarian Writings from Qumran, JSPSup 11 (Sheffield: Bloomsbury, 1992), most recently also M.A. Walsh, Angels Associated with Israel in the Dead Sea Scrolls: Angelology and Sectarian Identity at Qumran, WUNT 2/509 (Tübingen: Mohr Siebeck, 2019).

60 On this, see Jost, Engelgemeinschaft (see n. 33), 28-30.

61 On this text, cf. A. Steudel, Der Midrasch zur Eschatologie aus der Qumrangemeinde (4QMidrEschat $\left.{ }^{a . b}\right)$. Materielle Rekonstruktion, Textbestand, Gattung und traditionsgeschichtliche Einordnung des durch 4Q174 ("Florilegium”) und 4Q177 (“Catena A") repräsentierten Werkes aus den Qumranfunden, StTDJ 13 (Leiden: Brill, 1994).

62 Cf. Steudel, Der Midrasch (see n. 61), 165-166. It is, in my view, questionable to call this spiritualization, since the term implies a reduced degree of reality. For the Qumranites, however, the degree of reality of the angelic or divine presence was rather enhanced when this was considered present in the community meetings. 
perfection” (1QS IX, 6). For the Qumran community, this was not a hope related to any future periods but a conviction that referred to the present, in which the earthly sanctuary, the Jerusalem Temple, was considered contaminated and participation in a halakically "correct" sacrificial cult was impossible.

Closely linked to this is the specific idea of the present possibility of communion with the angels. ${ }^{63}$ In a significant passage of the Hodayot, in reference to one's entry into the Essene community, it is said that the depraved spirit, cleansed by God, "takes its place with the army of the holy ones and enters into communion with the community of the sons of heaven." ${ }^{64}$ In 1 QS XI, 7-8, it is analogously formulated that God "made [the elect] heirs in the lot of the holy ones ... and he has united their community with the sons of heaven in a common council of the community and in a circle of the sacred building" $\left(1 \mathrm{QH}^{\mathrm{a}} \mathrm{XI}, 22-24\right)$. That is, those who entered into the end-time covenant are now explicitly considered to be a part of a community of heavenly and earthly beings, and the members of the community were convinced that in their earthly cult, that is, the gathering of their community (and in their status of purity) they participated in the heavenly cult (cf. 1QSb III, 25-26; 1QH ${ }^{\mathrm{a}} \mathrm{XIX}, 17,28-29$ ).

\subsubsection{An Interim Balance}

It is clear that the Qumran community's thinking is deeply rooted in many aspects of apocalyptic traditions. The reception of Danielic and Enochic traditions, including Jubilees and the reception of other associated texts that belong to the genre "apocalypse," confirms this, as well as the broad reception of motifs that actually belong to the stock of apocalyptic thought.

The motifs described here are adopted from a wider variety of sources. Eschatological aspects are linked with the calendric wisdom in the background of the Enochic tradition. The details of angelology are taken from both the Enochic tradition and from the texts of some pre-sectarian priestly circles. The cosmic and eschatological dualism as represented in the Treatise on the Two Spirits was developed from sapiential traditions. The heptadic chronological patterns are based on the use of Jeremiah's prophecy and its later interpretation by Daniel. In the yahad community, however, all these motifs are shaped by the community's specific awareness of its election and the special quality of the present

63 See the earlier compilation of passages in Kuhn, Enderwartung (see n. 58), 67-68 and now more comprehensively M. Jost, Engelgemeinschaft (see n. 33), 72-195.

$641 \mathrm{QH}^{\mathrm{a}} \mathrm{XI}, 21-22$. 
period, as well as by the particular focus of the Qumranites on the interpretation of inspired writings. Therefore, other forms of revelatory mediation, as are wellknown from the apocalyptic tradition, ${ }^{65}$ along with the authorization of particular insights by the pseudonymous reference to certain forefathers could be left aside in the group-specific texts without the apocalyptic motifs becoming less significant.

\section{The Understanding of Time and History in the Qumran Community}

But how can we describe, against the background sketched above, how the Qumran Community understood time and history, and how they understood their own place within time and history.

\subsection{Historical References}

It is perhaps not too simple to start with an initial observation. The Qumran Corpus is almost entirely void of precise historical references. There is no clear synchronization with world history, with kingdoms or rulers, as we can find in historical works, or even in the Gospel of Luke where John and Jesus are connected with the rules of Tiberius and Augustus (Luke 2:1; 3:1), nor is there any unambiguous reference to external historical events. Although the Qumranites were well aware of the political processes around them and even commented on some of them in a veiled manner, they did not consider them fundamental for their own worldview and self-definition, nor did they use the genre of historiography in their literary production. Israelite and foreign rulers are all part of a "history" that is considered fundamentally determined by God and his plan rendering them not important as such.

In the whole Qumran Corpus, there is only one short text that can be linked with a known ruler: In 4Q448, there is a fragmentary copy of a non-sectarian psalm and, then, probably by another hand, a text that praises and prays for "King Jonathan," that is the Jewish king Alexander Jannaios. The scribe probably wanted to relate the preceding psalm to that king, possibly on the occasion of his

65 Cf. A. Lange, "The Essene Position on Magic and Divination," in Legal Texts and Legal Issues, ed. M. Bernstein, F. García Martínez, and J. Kampen, Festschrift J.M. Baumgarten, StTDJ 23 (Leiden et al.: Brill, 1997), 377-435. 
victory over the Seleucid kind Demetrios III, that helped to protect Jerusalem from foreign enemies. ${ }^{66}$ But we cannot decide whether the complement of texts on this manuscript was crafted within the community or rather from an external individual who actually supported the Hasmonean ruler. ${ }^{67}$

In any case, the number of letters or documentary texts in the corpus is extremely small. ${ }^{68}$ One text documents a rebuke of members by an official in the community - thus this text (4Q477 Rebukes of the Overseer) is a well-preserved documentary text - but it attests to administration processes within the community, probably even at the location of Khirbet Qumran.

In the literary texts, instead, the persons linked with certain events are usually mentioned by a "nickname": Not only the "Righteous Teacher" but also the "Wicked Priest" and the "Man of Lies" are hidden behind their nicknames, so that their historical identity might have been deciphered by readers from the community. However, the identification of, for example, the Righteous Teacher and the Wicked Priest is debated, and there is at least the possibility that these designations (at least at a certain time), could be transferred to various historical persons or were, at least in the end, used without a particular historical figure in view. ${ }^{69}$ However, in my view, it is still plausible that certain conflicts from the formative period of the community shaped the community's collective memory, so that the references still point to historical figures in the history of the community or also of Palestinian Judaism in the $2^{\text {nd }}$ century BCE.

66 Cf. H. Stegemann, Die Essener, Qumran, Johannes der Täufer und Jesus (Freiburg i.Br.: Herder, 1993), 187-188.

67 Thus H. Eshel, The Dead Sea Scrolls and the Hasmonean State (Grand Rapids, MI: Eerdmans; Jerusalem: Yad Ben-Zvi, 2008), 101-116. The fact that Jonathan is linked with his whole people shows a pan-Israelitic and, thus, non-aectarian viewpoint.

68 There are some very fragmentary texts that might be classified as "historical” (e. g., 4Q332 and 4Q333), but the names mentioned there cannot be linked with known figures. See the texts in The Dead Sea Scrolls Reader, vol. 6: Additional Genres and Unclassified Texts, ed. D.W. Parry and E. Tov (Leiden: Brill, 2005), 2-6.

69 Many scholars identify the "Righteous Teacher" (or "Teacher of Righteousness") with a highpriestly figure in the history of Israel and the "Wicked Priest" with one of the Hasmonean Rulers, most probably Jonathan (thus Stegemann, Die Essener [see n. 66], 205-213). An important alternative concept was developed in the so-called Groningen Hypothesis with the idea that the names do not refer to a distinct historical person but rather to a role or function adopted by various persons. Such a later function of the names cannot be ruled out, but it does not necessarily contradict the idea that there was a central conflict with particular personalities involved at the beginning of the movement. 


\subsection{The Prehistory and History of the Community according to the Damascus Document}

Glimpses into the history of the community or at least in their own construction of their history can be gained from the overviews in the Damascus Document or, as its title is preserved in one of the $4 \mathrm{Q}$ manuscripts, "the last exploration of the Torah" (4Q266 XI, 18-21). This title shows an eschatological awareness, in the sense that the interpretation of the Law presented here is the definitive one and, consequently, the community practicing those laws is located in an eschatological period.

The document was most likely written around 100 BCE. $^{70}$ The text already looks back on the work (CD I, 11) and death of the "Teacher of Righteousness" (CD XX, 14) and localizes their own present in the last era after his death, which was expected to last for another 40 years (CD XX, 15). This shows that the writing draws on a view of history structured in distinct periods, which are predetermined by God for all times (CD II, 9-10). In addition to the law of Moses, CD XVI, 2 references the "book of the division of ages after their jubilees and their weeks (of years)," which is presumably the book of Jubilees, whose chronological structuring of time, in addition to the Mosaic Torah, was foundational for the Qumran Community. This demonstrates that the yahad adopted its understanding of the periodization of history from certain apocalyptic traditions. $^{71}$

The basic data are presented in the opening historical overview in CD I: First of all - in good Deuteronomistic terms - the destruction of Jerusalem and the exile are interpreted as punishment for sins and as a sign that God had abandoned Israel (I, 3-4). The post-exilic period is, then, regarded as the "time of wrath," and the presence of the community is still seen under this sign. ${ }^{72}$ But in this "time of wrath," a remnant in Israel is not abandoned for destruction, instead, there emerges a sprout of a plant from it. This is an imagery we also know from the Book of Watchers (1 En. 10:16) and from the Enochic Apocalypse of Weeks (1 En. 93:10) where there is also mention of a "planting of righteousness" emerging during the $7^{\text {th }}$ week (i.e., the age of the author and the addressees).

70 Cf. C. Wassen, "The Damascus Document," in Early Jewish Literature: An Anthology, ed. B. Embry, R. Herms, and A.T. Wright, vol. 2 (Grand Rapids, MI: Eerdmans, 2018), 128-159, here 132.

71 Collins, "Dead Sea Sect" (see n. 10), 280: "There is good reason, then, to believe that the members of the new covenant acquired their periodization of history from apocalyptic sources." $72 \mathrm{CD} \mathrm{I}, 5$ does not mean that this time would be over with the visitation of the remnant. 
This can now be combined with the (ideal) chronology offered in CD I: The visitation is said to begin 390 years after the exile, when the remnant begins to turn to repent and seek God (I, 5-6). Twenty more years, it is said, were the repentant "like the blind" and those who grope for a way (I, 9-10). Then God rose up a righteous teacher for them (I, 11). If we conjecture another period of 40 years for the time of the teacher's ministry and the 40 years mentioned in $\mathrm{CD}$ $\mathrm{XX}, 15$ as the time from his departure to the end of this particularly troublesome time, then there would be a whole of 490 years, that is, 70 weeks of years (Dan 9) or ten jubilees for the "time of wrath." It is during this particularly violent period of time, in close expectation of the end, that the addressees of the Damascus Document live.

Of course, there are uncertainties in this calculation: The 390 years could be derived from Ezek 4:5, and an exact calculation starting with the year of the Temple destruction of 587/586 BCE does not lead to any known event, but only roughly points to the early $2^{\text {nd }}$ century BCE. Two further numbers (20 and 40) are given in the Damascus Document, but the duration of the teacher's ministry, calculated by another 40 years must be conjectured. But the number of those 40 years is not derived from biblical periods (e.g., Israel's time in the wilderness). It could also approximate historical reality. In any case, the sum of 490 years is plausible on the background of other heptadic calculations, as in Jubilees and in the Apocalypse of Weeks, and with that time frame, regardless of the exact dates applied for the Righteous Teacher, the composition of the Damascus Document can be located toward the end of that "great week" or "great jubilee."

But how is the present of the community described? It is located in the "time of wrath," and in CD IV, 13-15 the text explains that this means that it is in a particular manner afflicted by the eschatological opponent Belial: "In all these years Belial will be set against Israel” (CD IV, 13), trying to seduce the pious with his three "nets" (CD IV, 15). In CD XVI, 5, instead of the name "Belial" the term "malakh ha-mastema" (angel of enmity) is encountered, which is evidently a reference to the name "Mastema," used in Jubilees for the prince of demons. CD XII, 2 speaks of the "spirits of Belial" reigning over a human (cf. Jub. 1:20; spirit of Belial). These terminological similarities confirm that the Damascus Document is closely connected with Jubilees with regard to the names for the adversary. Interestingly, it does not refer to the names of the two spirits as presented in the Treatise on the Two Spirits (1QS III, 13-IV, 26, whose determinism, on the other hand, is also well received. ${ }^{73}$

73 On the reception of the Treatise in the Damascus Document, see Frey, "Different Patterns" (see n. 32), 269-270. 
Belial is considered to be unleashed against Israel during the time of the community's existence. Only those who have entered into the covenant are preserved from his afflictions. Indeed, with the entrance into the covenant, the "angel of enmity" abates. Here we encounter an essential aspect of the community's elitist consciousness of being specifically elected. This is also the difference between earlier concepts of dualism in which the opposition is still set between Israel and the nations, or, as in the Treatise on the Two Spirits, the fight is still ongoing within every human individual. Now, in the sectarian setting, the dividing line runs within Israel, namely between insiders and outsiders, between the members and non-members of the yahad community. ${ }^{74}$

\subsection{The Periodization of History and Heptadic Patterns}

According to the Damascus Document, the community is located in a structured and predetermined sequence of events in the end time. In this theology of history, the Damascus Document has its closest predecessors in texts such as the Enochic Apocalypse of Weeks or the book of Jubilees where the chronological patterns are basically derived. According to the determinism expressed in the Damascus Document, God has established the times in advance, according to a heptadic structure of jubilees and "weeks" of years, so that even the end can be chronologically recorded, although the precise sequence of past, present, and expected events is not specified. In a slightly younger text, the Pesher Habakkuk, it must even be argued why this "last age" extends beyond the supposed date of the end (1QpHab VII). These remarks probably do not point to an "end of the world" stricto sensu, but - more probably - to an expected end of the "time of wrath" with the destruction of the wicked (CD XX, 14), which was expected to be followed by a new period of the salvation or welfare of the pious (CD XX, 33-34). This perspective also corresponds to the Apocalypse of Weeks where after the present $7^{\text {th }}$ week three more weeks of judgments and emerging final "shalom" are foreseen, and also to the apocalyptic outlook in Jubilees 23 where the movement of repentance leads to a restoration of humankind (expressed again by an prolonged lifetime of humans up to 1000 years) and to endless righteousness and peace on earth.

We can supplement this from a number of other texts. In the so-called Ages of Creation (4Q180-181), God's predetermination of history is emphasized (4Q180 I, 1-3): “interpretation concerning the ages which God has made: An

74 Cf. Frey, “Different Patterns” (see n. 32), 291-295. 
age to conclude [all that there is] and all that will be. Before creating them, he determined [their] operations [according to the precise sequence of the ages,] one age after another age. And it is engraved on the [heavenly] tablets." 75 Thus, the course of history and eschatology is firmly laid down on eternal tablets (in analogy with the tablets of the Law) in heaven. This matches the idea of Jubilees that an angel of the presence dictated to Moses from heavenly tablets (Jub. 1:27). In the "Ages of Creation," the story of the Watchers and the story of the flood are told, but those events are not merely events in history. Instead, they were already known to the creator before the creation ${ }^{76}$ and thus part of an eternal or eternally predetermined reality.

The dependence on a heptadic chronological pattern can also be seen in the famous Melchizedek text 11QMelch (col. ii) where the law for the return of property in the $50^{\text {th }}$ year, the jubilee, is interpreted as a prophecy of the "last days," in which the "jubilee to the captives" is proclaimed (Isa 61:1) and Melchizedek "will return to them what is rightfully theirs" (11QMelch ii, 5). Melchizedek as a heavenly or angelic redeemer figure is said to "atone for all the sons of light," to "judge God's holy ones," and to "establish a righteous kingdom" (11QMelch ii, $8-9)$. As in the book of Jubilees, where the liberation of Israel from Egypt happened in the $50^{\text {th }}$ jubilee of the world, and a further liberation is to be expected in the $100^{\text {th }}$ jubilee, ${ }^{77}$ so also in the Melchizedek midrash the time of deliverance is described as being linked to a jubilee, a certain predestined time, according to a heptadic chronological pattern.

\subsection{The Pesharim and the History of the Community}

A closer relation between Scripture and history, or more precisely the history of the community, is presented in the Pesharim, the particularly Qumranian genre of scriptural interpretation that was probably developed by the yahad community. The hermeneutical presupposition of this interpretive technique is openly expressed in the Habakkuk-Pesher (1QpHab). The prophets of old who spoke or wrote the words of Scripture did not know to what their words referred. Only the insight of the community, or more precisely the insight of the Righteous Teacher "to whom God made known all the mysteries of the words of his serv-

75 Translation according to The Dead Sea Scrolls Study Edition, ed. and trans. F. García Martínez and E.J.C. Tigchelaar, 2 vols. (Leiden et al.: Brill, 1997), 2:371-375.

76 4Q418 2-4 ii, 10: "before He created them he knew [their] thoughts."

77 Cf. J. Frey, “The Worldview in the Book of Jubilees," in idem, Qumran, Early Judaism, and New Testament Interpretation, 429-460, here 437-439. 
ants the prophets" (1QpHab VII, 4-5) allows for an understanding of those words. This means that the words of the prophets do not aim at the time in which the prophets lived, but at the "end of days," that is, the present period, in which the eschatological community lives. Thus, unlike a modern biblical commentary, the pesher does not interpret all aspects of the biblical text quoted but only the elements that could be related to the history of the community or its enemies: the Wicked Priest in his opposition to the Righteous Teacher, or also the "Kittim." The "Chaldeans," who are the opponents in the biblical text (Hab 1:6), are now related to the "Kittim" (1QpHab II, 11-12) who are described in the commentary as swift and powerful, possessing many countries, unbelieving (1QpHab II, 14-15), coming with war horses (1QpHab III, 7-8) and ships from the islands (1QpHab III, 11), trampling the land with their horses (1QpHab III, 10), attacking cities and plundering them. Quite precisely, it is said that they "worship their standards" (1QpHab VI, 4), and this is a very clear sign that the Romans are meant here. Thus, the present situation not only of the community but also of the people, the Roman occupation of the East, probably with Pompeius entering the Jerusalem temple, is found foretold in the Scriptures, and according to the self-confidence of the community, those foretellings can be deciphered now, due to the revelation received in the yahad.

The yahad has adopted essential elements of the view of history from presectarian apocalypses and adapted this image to its own consciousness of election and special revelation. This is an apocalyptic view of time and history. It does not directly claim heavenly authority but emerges from the authority of an inspired interpretation of the Torah with the help of apocalyptic traditions.

The calculation of time presented in the Damascus Document probably led to the expectation that the final visitation should happen 40 years after the death of the Righteous Teacher. The concern about the fact that the end did not come at that appointed time is, then, mirrored in 1QpHab VII, 6-8 where in the interpretation of Hab 2:3 it is said: "This means that the Last Days will be long, much longer than the prophets had said, for God's revelations are truly mysterious." Apparently the end did not come at the expected time, instead history went on, the Romans conquered the land, and Pompeius entered the Holy Temple in Jerusalem. In that affliction, the Qumranites develop a kind of theory about the delay of the end, quite similar to what happened later also in the Jesus movement. 


\section{Concluding Perspectives}

From the very selective sketch of eschatological views of the Qumran Community, we can develop some concluding perspectives.

1. The Qumran community's understanding of time and history is clearly taken from apocalyptic traditions, including calendric traditions with a heptadic world chronology. It is further intensified by a particular awareness of a special revelation that was given to the community by the Righteous Teacher that enabled them to understand not only the correct meaning of the Law (in terms of a very rigid halakha) but also the meaning of the words of the prophets in their relation to the present time of the community.

2. Based on chronological patterns derived from apocalyptic texts, the community considered itself to be living within the "end of the days," in a period still dominated by Belial and his afflictions, but already close to the final visitation which is, however, not imagined coherently. As is well-known, the Qumran Corpus has made us aware of a wide plurality of Messianic concepts and figures in Second Temple Judaism, and even within the texts of clearly sectarian origin, there are various eschatological and messianic expectations next to each other.

3. The tension between the expectation and the real history that had to be explained and biblical texts such as Hab 2:3 provided a textual hint to understand this. On the other hand, the community did not abandon its view that the end or the final visitation with the removal of evil and the deliverance of the pious was determined. In our modern understanding, such a world-view may be considered not only speculative but even stubborn. However, particularly in a period in which the world is seen in serious tribulations, under the dominion of foreign and evil powers, it is a forceful conviction that this time of tribulation is limited and that the deliverance is certain, that there is a final justice, and that evil will not go unpunished and piety will get its reward. This is the worldview established in the early apocalyptic tradition, and it seems to have been particularly useful in coping with life in times of oppression by foreign powers and the experience of impiety even within God's people. Such apocalypticism did not become outdated, even when the course of history went on differently. Instead, the apocalyptic images could prove their motivating force in changed situations, and the apocalyptic way of understanding the respective present and future became a prevailing tradition, not only in ancient Judaism, but even more so in the Jesus movement and the later Christian tradition. 


\section{Bibliography}

Albani, M., Astronomie und Schöpfungsglaube: Untersuchungen zum Astronomischen Henochbuch, WMANT 68 (Neukirchen-Vluyn: Neukirchener Verlag, 1994).

Becker, M., "Die 'messianische Apokalypse' 4Q521 und der Interpretationsrahmen der Taten Jesu," in Apokalyptik und Qumran, ed. M. Becker and J. Frey, Einblicke 10 (Paderborn: Bonifatius, 2007), 247-303.

Collins, J. J., "Apocalypticism and Literary Genre in the Dead Sea Scrolls," in The Dead Sea Scrolls After Fifty Years: A Comprehensive Assessment, vol. 2, ed. P. W. Flint and J. C. VanderKam (Leiden et al.: Brill, 1999), 403-430.

Collins, J. J., Apocalypticism in the Dead Sea Scrolls (London: Routledge, 1997).

Collins, J. J., "Genre, Ideology and Social Movement in Jewish Apocalypticism," in Mysteries and Revelations: Apocalyptic Studies since the Uppsala Colloquium, ed. idem and J. H. Charlesworth, JSPSup 9 (Sheffield: JSOT, 1991), 11-32.

Collins, J. J., "Introduction: Towards the Morphology of a Genre," in Apocalypse: The Morphology of a Genre, ed. idem, Semeia 14 (Misoula, MT: SBL, 1979), 1-20.

Collins, J. J., The Apocalyptic Imagination (New York, NY: Crossroad, 1984).

Collins, J. J., "The Book of Daniel and the Dead Sea Scrolls," in idem, Scriptures and Sectarianism: Essays on the Dead Sea Scrolls, WUNT 332 (Tübingen: Mohr Siebeck, 2004), 87-101.

Collins, J. J., "The Origin of Evil in Apocalyptic Literature and in the Qumran Community," in idem, Seers, Sibyls and Sages in Hellenistic-Roman Judaism, JSJSup 54 (Leiden: Brill, 1997), 287-300.

Collins, J. J., "Was the Dead Sea Sect an Apocalyptic Movement," in idem, Seers, Sibyls and Sages in Hellenistic and Roman Judaism, JSJSup 54 (Leiden: Brill, 1997), 261-286.

Collins, J. J., and Flint, P. W., "Pseudo-Daniel," in Qumran Cave 4 XVII: Parabiblical Texts, ed. G. Brooke et al., vol. 3, DJD 22 (Oxford: Clarendon Press, 1996), 95-163.

Davidson, M. J., Angels at Qumran: A Comparative Study of 1 Enoch 1-36, 72-108 and Sectarian Writings from Qumran, JSPSup 11 (Sheffield: Bloomsbury, 1992).

Eshel, H., The Dead Sea Scrolls and the Hasmonean State (Grand Rapids, MI: Eerdmans; Jerusalem: Yad Ben-Zvi, 2008).

Fitzmyer, J. A., “The Aramaic 'Son of God' Text from Qumran Cave 4 (4Q246)," in idem, The Dead Sea Scrolls and Christian Origins (Grand Rapids, MI: Eerdmans, 2000), 41-61.

Flint, P. W., "The Prophet Daniel at Qumran," in Eschatology, Messianism, and the Dead Sea Scrolls, ed. C. A. Evans and P. W. Flint (Grand Rapids, MI: Eerdmans, 1997), 41-60.

Frey, J., “Apocalyptic Dualism: Its Formation and History," in idem, Qumran, Early Judaism, and New Testament Interpretation, ed. J. N. Cerone, WUNT 424 (Tübingen: Mohr Siebeck, 2019), 321-324.

Frey, J., "Different Patterns of Dualistic Thought in the Qumran Library," in idem, Qumran, Early Judaism, and New Testament Interpretation, ed. J. N. Cerone, WUNT 424 (Tübingen: Mohr Siebeck, 2019), 243-299.

Frey, J., "Jesus und die Apokalyptik," in idem, Von Jesus zur neutestamentlichen Theologie: Kleine Schriften II, ed. B. Schliesser, WUNT 368 (Tübingen: Mohr Siebeck, 2017), 85-157.

Frey, J., “On the Origins of the Genre 'Literary Testament': Farewell Discourses in the Qumran Library and Their Relevance for the History of the Genre," in idem, Qumran, Early 
Judaism, and New Testament Interpretation, ed. J. N. Cerone, WUNT 424 (Tübingen: Mohr Siebeck, 2019), 325-348.

Frey, J., "Qumran: An Overview," in idem, Qumran, Early Judaism, and New Testament Interpretation, ed. J. N. Cerone, WUNT 424 (Tübingen: Mohr Siebeck, 2019), 45-81.

Frey, J., “Qumran and Archaeology," in idem, Qumran, Early Judaism, and New Testament Interpretation, ed. J. N. Cerone, WUNT 424 (Tübingen: Mohr Siebeck, 2019), 121-161.

Frey, J., Qumran, Early Judaism, and New Testament Interpretation, ed. J. N. Cerone, WUNT 424 (Tübingen: Mohr Siebeck, 2019).

Frey, J., "The Authority of the Scriptures of Israel in the Qumran Corpus," in idem, Qumran, Early Judaism, and New Testament Interpretation, ed. J. N. Cerone, WUNT 424 (Tübingen: Mohr Siebeck, 2019), 403-428.

Frey, J., The Letter of Jude and the Second Letter of Peter: A Theological Commentary, trans. K. Ess (Waco, TX: Baylor University Press, 2018).

Frey, J., "The New Jerusalem Text in Its Historical and Traditio-Historical Context," in idem, Qumran, Early Judaism, and New Testament Interpretation, ed. J. N. Cerone, WUNT 424 (Tübingen: Mohr Siebeck, 2019), 349-368.

Frey, J., "The Qumran Discoveries and the Understanding of Apocalypticism," in idem, Qumran, Early Judaism, and New Testament Interpretation, ed. J. N. Cerone, WUNT 424 (Tübingen: Mohr Siebeck, 2019), 195-241.

Frey, J., "The Rule of the Community," in Early Jewish Literature: An Anthology, ed. B. Embry, R. Herman, and A. T. Wright, vol. 2 (Grand Rapids, MI: Eerdmans, 2018), 95-127.

Frey, J., "The Worldview in the Book of Jubilees," in idem, Qumran, Early Judaism, and New Testament Interpretation, ed. J. N. Cerone, WUNT 424 (Tübingen: Mohr Siebeck, 2019), $429-460$.

García Martínez, F., "Apocalypticism in the Dead Sea Scrolls," in The Encyclopedia of Apocalypticism, ed. J. J. Collins, vol. 1 (New York, NY: Bloomsbury, 2002), 162-192.

García Martínez, F., Foreword, in idem, Qumran and Apocalyptic. Studies on the Aramaic Texts from Qumran, StTDJ 9 (Leiden: Brill, 1992).

García Martínez, F., "Les traditions apocalyptiques à Qumrân,” in Apocalypses et voyages dans l'au-delà, ed. C. Kappler (Paris: Cerf, 1987), 201-235.

García Martínez, F., and Tigchelaar, E. J. C., ed. and trans., The Dead Sea Scrolls Study Edition, 2 vols. (Leiden et al.: Brill, 1997).

Götte, M. E., Von den Wächtern zu Adam: Frühjüdische Mythen über die Ursprünge des Bösen und ihre frühchristliche Rezeption, WUNT 2/426 (Tübingen: Mohr Siebeck, 2016).

Hogeterp, A. L. A., Expectations of the End: A Comparative Traditio-Historical Study of Eschatological, Apocalyptic and Messianic Ideas in the Dead Sea Scrolls and the New Testament, STDJ 83 (Leiden et al.: Brill, 2009).

Jost, M. R., Engelgemeinschaft im irdischen Gottesdienst Studien zu Texten aus Qumran und dem Neuen Testament, WUNT 2/505 (Tübingen: Mohr Siebeck, 2019).

Kaiser, O., Der Prophet Jesaja. Kapitel 13-39, $3^{\text {rd }}$ ed., ATD 18 (Göttingen: Vandenhoeck \& Ruprecht, 1983).

Kuhn, H.-W., Enderwartung und gegenwärtiges Heil: Untersuchungen zu den Gemeindeliedern von Qumran mit einem Anhang über Eschatologie und Gegenwart in der Verkündigung Jesu, SUNT 4 (Göttingen: Vandenhoeck \& Ruprecht, 1966). 
Lange, A., "The Essene Position on Magic and Divination" in Legal Texts and Legal Issues, ed. M. Bernstein, F. García Martínez, and J. Kampen, Festschrift J. M. Baumgarten, StTDJ 23 (Leiden et al.: Brill, 1997), 377-435.

Lichtenberger, H., “Auferstehung in den Qumranfunden," in Auferstehung-Resurrection, ed. F. Avemarie and H. Lichtenberger, WUNT 135 (Tübingen: Mohr Siebeck, 2001), 79-91.

Mach, M., Entwicklungsstadien des jüdischen Engelglaubens in vorrabbinischer Zeit, TSAJ 34 (Tübingen: Mohr Siebeck, 1992).

Milik, J. T., The Books of Enoch: The Aramaic Fragments from Qumran (Oxford: Oxford University Press, 1976).

Müller, K., “Die frühjüdische Apokalyptik: Anmerkungen zu den Anfängen ihrer Geschichte, zu ihrem Erscheinungsbild und zu ihrer theologischen Wertung," in idem, Studien zur frühjüdischen Apokalyptik, SBAB 11 (Stuttgart: Katholisches Bibelwerk, 1991), 36-174.

Nickelsburg, G. W. E., Resurrection, Immortality and Eternal Life in Intertestamental Judaism, HTS 26 (Cambridge, MA: Harvard University Press, 1972).

Nickelsburg, G. W. E., "The Books of Enoch at Qumran. What We Know and What We Need to Think about," in Antikes Judentum und Frühes Christentum, Festschrift Hartmut Stegemann, ed. B. Kollmann, W. Reinbold, and A. Steudel, BZNW 97 (Berlin: de Gruyter, 1999), 99-113.

Nickelsburg, G. W. E., 1 Enoch 1: A Commentary on the Book of 1 Enoch, Chapters 1-36; 81-108, vol. 1, Hermeneia (Minneapolis, MN: Fortress, 2001).

Nickelsburg, G. W. E., and VanderKam, J. C., 1 Enoch 2: A Commentary on the Book of 1 Enoch, Chapters 37-82, Hermeneia (Minneapolis, MN: Fortress Press, 2012).

Parry D. W., and Tov, E., eds., The Dead Sea Scrolls Reader, vol. 6: Additional Genres and Unclassified Texts (Leiden: Brill, 2005).

Puech, É., “4QApocryphe de Daniel ar," in Qumran Cave 4 XVII, ed. G. Brooke et al., DJD 22 (Oxford: Oxford University Press, 1996), 165-184.

Puech, É., La croyance des Esséniens en la vie future: immortalité, résurrection, vie éternelle?, EtBib 22 (Paris: Gabalda, 1993).

Schmid, J. M., Die jüdische Apokalyptik: Die Geschichte ihrer Erforschung von den Anfängen bis zu den Textfunden von Qumran (Neukirchen-Vluyn: Neukirchener Verlag, 1969).

Stegemann, H., “Die Bedeutung der Qumranfunde zur Erforschung der Apokalyptik” in Apocalypticism in the Mediterranean World and the Near East, ed. D. Hellholm, $2^{\text {nd }}$ ed., (Tübingen: Mohr Siebeck, 1989), 495-530.

Stegemann, H., Die Essener, Qumran, Johannes der Täufer und Jesus (Freiburg i. Br.: Herder, 1993).

Steudel, A., Der Midrasch zur Eschatologie aus der Qumrangemeinde (4QMidrEschat ${ }^{a . b}$ ). Materielle Rekonstruktion, Textbestand, Gattung und traditionsgeschichtliche Einordnung des durch 4Q174 ("Florilegium") und 4Q177 ("Catena A") repräsentierten Werkes aus den Qumranfunden, StTDJ 13 (Leiden: Brill, 1994).

Stuckenbruck, L. T., The Book of Giants from Qumran, TSAJ 63 (Tübingen: Mohr Siebeck, 1997).

Stuckenbruck, L. T., "The Origins of Evil in Jewish Apocalyptic Tradition: The Interpretation of Genesis 6:1-4 in the second and third Centuries B.C.E," in The Fall of the Angels, ed. C. Auffahrt and L. T. Stuckenbruck, TBN 6 (Leiden: Brill, 2004), 87-118. 
Tov, E., "Categorized List of the "Biblical Texts," in The Texts from the Judean Desert: Indices and Introduction to the Discoveries in the Judaean Desert Series, ed. idem, DJD 39 (Oxford: Oxford University Press, 2002), 165-184.

Ulrich, E., "Index of Passages in the 'Biblical Texts'," in The Texts from the Judean Desert Indices and Introduction to the Discoveries in the Judaean Desert Series, ed. E. Tov, DJD 39 (Oxford: Oxford University Press, 2002), 185-201.

Walsh, M. A., Angels Associated with Israel in the Dead Sea Scrolls: Angelology and Sectarian Identity at Qumran, WUNT 2/509 (Tübingen: Mohr Siebeck, 2019).

Wassen, C., "The Damascus Document," in Early Jewish Literature: An Anthology, ed. B. Embry, R. Herms, and A. T. Wright, vol. 2 (Grand Rapids, MI: Eerdmans, 2018), $128-159$.

Yarbro Collins, A., "Introduction: Early Christian Apocalypticism," in Early Christian Apocalypticism: Genre and Social Setting, ed. eadem, Semeia 36 (Decatur, GA: SBL, 1986), 1-11.

Zimmermann, J., Messianische Texte aus Qumran, WUNT 2/104 (Tübingen: Mohr Siebeck, 1998). 